\title{
Mathematics Teachers' Perceptions of Soft Skills Integration in Mathematics Teaching and Learning in Secondary Schools in Mazabuka District, Zambia
}

\author{
Chileshe Busaka* \\ African Centre of Excellence for Innovative Teaching and Learning Mathematics \\ and Science (ACEITLMS), University of Rwanda, Rwanda \\ Septimi Reuben Kitta \\ University of Dar es Salaam, Tanzania \\ Odette Umugiraneza \\ College of Education (UR-CE), University of Rwanda, Rwanda
}

\begin{abstract}
Mathematics teachers' perceptions of soft skills integration are key to ensuring students' soft skills development. The present study investigated perceptions regarding the integration of soft skills in teaching and learning mathematics in Mazabuka District in Zambia. Ninety-one teachers, who were selected purposively, completed a questionnaire and a test on the integration of soft skills in teaching and learning mathematics. Frequencies, means, and standard deviations were calculated, and independent sample t-test and analysis of variance (ANOVA) were used to analyze the data. The findings are that mathematics teachers had a positive perception of soft skills integration in mathematics and believed that incorporating soft skills in teaching and learning mathematics was important. Furthermore, the results reveal that mathematics teachers' gender and age, the type of school where they taught, their experience and level of education did not influence their perceptions of soft skills integration in mathematics teaching and learning in Zambian secondary schools.
\end{abstract}

Keywords: mathematics teachers; perceptions; soft skills integration; importance of soft skills; mathematics; secondary schools

\footnotetext{
* Corresponding author: Chileshe Busaka, chilebusaka2006@yahoo.co.uk 


\section{Introduction}

\subsection{Background to the Problem}

Globally, there is a demand for the holistic development of students - for socalled soft and technical skills to be developed equally to enable students to adapt to a society that is gradually becoming more complex (Solórzano et al., 2018). Soft skills are described as the "intra- and interpersonal skills vital for personal development, social participation, and workplace success" (Quieng et al., 2015). Sharma (2009) and Agcam and Dogan (2021) describe soft skills as survival skills, which include teamwork, negotiation, communication, problemsolving, time management, interpersonal skills, and emotional intelligence. Soft skills are needed for various activities, and influence how people work or interact with others. DiMartino and Castaneda (2007) articulate that soft skills, such as communication, time-management, problem-solving, personal accountability, critical thinking, and collaboration, are among the requirements for employment seekers. Soft skills are considered to be key attributes that differentiate job aspirants with the same technical expertise, in all fields of work (Sutton, 2002) and "have proven to be determinant in teachers' educational action" (Fernandes et al., 2021).

Soft skills integration in teaching and learning is a component of the outcomebased curriculum adopted by the Curriculum Development Centre (CDC), which is an institution mandated to develop the curriculum for preprimary, primary and secondary schools in Zambia (CDC, 2013a). Since the Zambian curriculum requires the incorporation of soft skills in teaching and learning, teachers' perceptions of the integration of these skills in mathematics is vital. Various studies have found that the teacher's perceptions of soft skills integration in teaching and learning of mathematics could influence student learning (Rini \& Prabawanto, 2021). According to Calhoun (2019), several researchers submit that "teachers are the keys to improving student achievement in mathematics and identify teacher perception as an essential factor at the core of teaching and learning" (p. 1). If teachers hold positive perceptions of soft skills, it might contribute to developing students' critical thinking, problemsolving skills, collaboration, and teamwork, and improve their performance in mathematics. Gibb (2014) argues that equipping students with soft skills is likely to not only empower them, but also to reinforce their growth, participation in learning and employment success.

Based on the above, this study endeavored to establish mathematics teachers' perceptions of soft skills integration, as teacher perception is key to ensuring that students' soft skills are developed. The other underlying principle of this study was to investigate mathematics teachers' perceptions of the importance of integrating soft skills in mathematics lessons, and the factors that are associated with teachers' perceptions. This study was, therefore, needed, as it investigated what teachers think about soft skills integration and its importance in teaching and learning mathematics. As far as the researchers were aware, no study on this topic has been conducted in Zambian schools. 


\section{Literature Review}

\subsection{Teachers' perceptions of soft skills integration in secondary schools}

Mathematics teachers' perceptions are key to ensuring that the soft skills that are reflected in the 2013 revised curriculum, such as collaboration, critical thinking, communication, self-management, entrepreneurship, and creativity and innovation (CDC, 2013b), are integrated in mathematics. Emmanuel and Frank (2020) conducted a study on teachers' perceptions of soft skills integration in secondary schools, to establish the perceptions of men and women of soft skills integration in teaching business studies. The study was conducted in Rivers State in Nigeria, and 262 business studies teachers participated. The mean, standard deviation and independent samples t-test were used to analyze the research questions. Their findings show no statistically significant differences between female and male teachers' perceptions of soft skills integration.

A study by Calhoun (2019) conducted in the southern part of the United States of America with a sample of 315 mathematics teachers concludes that teachers' perceptions of self efficacy might influence students' achievement. Calhoun objectively intended to establish mathematics teachers' perceptions of their own self-efficacy and the effects of these perceptions on their professional performance in the roles they execute. The sample in Calhoun's study was a mixture of two levels of learning: 39 teachers taught in secondary schools and 279 taught in primary schools. The same conclusion was reached by Minarni et al. (2018) in a study conducted in Yogyakarta, Indonesia, which involved descriptive statistics, independent samples t-test and one-way ANOVA (analysis of variance) for reviewing and synthesising different studies. The study focused on exploring mathematics teachers' perceptions and how it impacts on their teaching practice.

In turn, a study by Susilawati et al. (2020), also in Yogyakarta, Indonesia, surveyed 100 science teachers drawn from junior secondary schools, and reports that soft skills acquired during the learning process are indispensable characteristics that impact significantly on students' achievement. Furthermore, teachers' perceptions of the importance of soft skills are a precursor to successful soft skills integration in teaching and learning processes. Failure to realize this phenomenon could be an impediment to soft skills development in students (Susilawati et al., 2020).

Furthermore, Free (2017) examined the perceptions of 125 secondary school agricultural science teachers in Alabama of the importance of soft skills integration into curriculums, and found that teachers had positive perceptions, with a mean score of $\geq 4.75$. It was found that the agricultural science teachers integrated soft skills into their teaching and learning. The participants indicated that soft skills were important, by responding on a 5-point Likert scale that ranged from not important to extremely important; the mean score was $\geq 4.22$ (Free, 2017).

Kobalia and Garakanidze (2010) acknowledge that students with soft skills contribute effectively to the development of their societies. This is because students can be creators and innovators of new ideas, in addition to being able to 
collaborate, communicate, think critically, and manage themselves, among other soft skills (CDC, 2013c; Kenya Institute of Curriculum Development [KICD], 2017; Rwanda Education Board [REB], 2015). Therefore, teachers' perceptions of the importance of soft skills have a bearing on how they integrate these skills in the teaching and learning of mathematics.

It has been found that demographic factors influence teachers' perceptions. In support of this finding, Baker et al. (2015) state that teacher characteristics, such as gender, type of school, age, level of education, and experience, have the potential to influence teachers' perceptions. Mailizar et al. (2021) examined teachers' knowledge in relation to demographic factors and found that there were significant differences in teachers' knowledge levels according to gender and education level; they found no significant differences between knowledge levels and teaching experience and school level. Thus, this study examined the relationship between mathematics teachers' demographic factors and their perceptions of soft skills integration. This study was necessary, due to its potential to uncover useful information, and because the reviewed studies had not been conducted in Zambia. There is a growing need to establish what mathematics teachers' perceptions of soft skills integration in mathematics is, particularly in secondary schools in Mazabuka District in Zambia.

\section{Theoretical Framework}

The social cognitive theory, particularly its concept of perceived self-efficacy, guided this study. Bandura (1997) defines perceived self-efficacy as beliefs or perceptions held by people regarding their perceptions of yielding chosen stages of performance that influence actions, which affect their lives. In other words, beliefs relating to self-efficacy influence how people think, feel, are motivated and, possibly, behave. Bandura's work suggests that one's belief in one's ability to alter one's behavior affects how one is motivated and, ultimately, whether one succeeds or fails. This theory is suitable for a study that intended to establish mathematics teachers' perceptions of soft skills integration, because, if mathematics teachers' perceptions are positive, it could influence positively the way they integrate soft skills in teaching and learning.

According to Bandura (1997), perceptions about one's capacity to positively impact one's situation influences how much effort one puts in, one's resilience to persist in the face of challenges and in dealing with failure, and how much stress or depression one experiences in dealing with demanding situations. Bandura's social cognitive theory emphasizes that human agency within a multi-directional model is purposive, constructive and planned (Cauce \& Gordon, 2012). In other words, "It involves anticipating the effects of our actions, estimating our capabilities, regulating and initiating effort" (Cauce \& Gordon, 2012, p. 3).

The motivations for and outcomes of our actions impact our influences, thoughts and behaviors (Flores, 2015). The concept of teachers' perceptions of disposition to adopt innovative teaching techniques has been associated with self-efficacy. In support of this notion, Darling-Hammond et al. (2002) state that "teachers' sense of efficacy and confidence about their ability to achieve teaching goals is significantly related to feelings of preparedness" (p. 295). It is the researchers' 
conviction that, if mathematics teachers' perceptions are positive, these perceptions could influence positively the way teachers integrate soft skills in mathematics teaching and learning, as expected (CDC, 2013a).

\subsection{Research Questions}

The following research questions guided the study:

i. What perceptions do mathematics teachers have about soft skills integration in mathematics teaching and learning in Zambian secondary schools?

ii. How important do mathematics teachers perceive the integration of soft skills in mathematics teaching and learning to be?

iii. Is there a relationship between mathematics teachers' demographic factors, such as gender, type of school, age, level of education, and experience, and perceptions of soft skills integration in mathematics teaching and learning in Zambian secondary schools?

\section{Methodology}

\subsection{Research Design}

A sequential multi-phase design for the collection and analysis of data (Saunders et al., 2016), guided the study. This type of research design involves a process that acknowledges that mixed methods research designs are interactive, and that one phase directs and informs the collection and analysis of data in the next phase (Ridenour \& Newman, 2008; Teddlie \& Tashakkori, 2009).

\subsection{Participants and their Demographic Factors}

This study approached 91 mathematics teachers to participate, of whom 81 completed and returned the questionnaire, constituting a return rate of $85.3 \%$. The mathematics teachers were purposively selected and drawn from secondary schools in the Mazabuka District in Zambia. The demographic factors of mathematics teachers are presented in Table 1.

Table 1: Frequencies and percentages of demographic factors of mathematics teachers who completed a survey questionnaire $(n=81)$

\begin{tabular}{llc}
\hline Factors & \multicolumn{1}{c}{ Description } & Frequency \\
\hline \multirow{2}{*}{ Gender } & Male & $48(59 \%)$ \\
& Female & $33(41 \%)$ \\
Age (in years) & $25 \leq \mathrm{X} \leq 34$ & $35(43 \%)$ \\
& $35 \leq \mathrm{X} \leq 54$ & $46(57 \%)$ \\
Type of school where & Non-public schools & $44(54 \%)$ \\
participants were teaching & Public schools & $37(46 \%)$ \\
& Diploma & $45(56 \%)$ \\
Education level of participants & Degree & $36(44 \%)$ \\
Teaching experience & $\leq 10$ & $44(54 \%)$ \\
(in years) & $>10$ & $37(46 \%)$ \\
\hline
\end{tabular}


The gender of mathematics teachers, as explained in Table 1, was reported as 48 $(59 \%)$ male and $33(41 \%)$ female. The ages of mathematics teachers who participated in the study ranged from 25 years to 54 years. The majority of these participants were in the age range 35 to 54 years $(n=46 ; 57 \%)$. The study took place at two types of schools, namely non-public and public. The teaching experience of mathematics teachers who participated in the study ranged from 1 year to 30 years; $44(54 \%)$ of the participants had maximum 10 years of experience teaching mathematics.

\subsection{Research Instruments}

To identify mathematics teachers' perceptions about soft skills integration in the teaching of mathematics at secondary school, they were asked to complete a selfreporting questionnaire and a test. The items included in the questionnaire were adapted from the scales used by other researchers in four different studies, as illustrated in Table 2.

Table 2: Items in the Scale Adapted from Four Studies

\begin{tabular}{|c|c|c|c|}
\hline Author & Study Title & $\begin{array}{c}\text { Items } \\
\text { Adapted }\end{array}$ & $\begin{array}{l}\text { Validation/ } \\
\text { Reliability }\end{array}$ \\
\hline $\begin{array}{l}\text { Yarkwah } \\
(2020)\end{array}$ & $\begin{array}{l}\text { "Mathematics teachers' } \\
\text { beliefs, their instructional } \\
\text { practices and its effects on } \\
\text { students' academic } \\
\text { performance" (p. 1). }\end{array}$ & $\begin{array}{l}\text { Teachers' } \\
\text { beliefs }\end{array}$ & Cronbach's alpha 0.77 \\
\hline $\begin{array}{l}\text { (Minarni et } \\
\text { al., 2018) }\end{array}$ & $\begin{array}{l}\text { "Mathematics teachers' } \\
\text { beliefs" (p. 1). }\end{array}$ & $\begin{array}{l}\text { Problem- } \\
\text { solving } \\
\text { and } \\
\text { creativity }\end{array}$ & $\begin{array}{l}\text { Synthesized various } \\
\text { scales using a method } \\
\text { of narrative reviews }\end{array}$ \\
\hline $\begin{array}{l}\text { Hoy and } \\
\text { Spero (2005) }\end{array}$ & $\begin{array}{l}\text { "Changes in teacher efficacy } \\
\text { during the early years of } \\
\text { teaching comparison of four } \\
\text { measures" (p. 343). }\end{array}$ & $\begin{array}{l}\text { Innovative } \\
\text { teaching }\end{array}$ & Cronbach's alpha 0.76 \\
\hline $\begin{array}{l}\text { Umugiraneza } \\
\text { et al. (2017) }\end{array}$ & $\begin{array}{l}\text { "Teachers' practices in } \\
\text { teaching Mathematics and } \\
\text { Statistics" (p. 1) }\end{array}$ & $\begin{array}{l}\text { Teaching } \\
\text { and } \\
\text { assessment }\end{array}$ & $\begin{array}{l}\text { Used qualitative } \\
\text { analysis to examine the } \\
\text { types of teaching and } \\
\text { assessments strategies }\end{array}$ \\
\hline
\end{tabular}

Table 2 shows the items of the questionnaire, which were answered by means of a 5-point Likert scale. The items of the test, which enquired about mathematics teachers' perceptions of the importance of soft skills, were developed according to the standards set for learning and innovation skills, developed by the Partnership for 21st Century Learning (P21) (Global Partnership for Education [GPE], 2020; Partnership for 21st Century, 2009). The learning and innovation skills in the Framework for $21^{\text {st }}$ Century Learning are creativity and innovation, critical thinking, communication, problem-solving and collaboration. These skills were assessed in a conceptual understanding test, and the findings were used to establish the extent to which mathematics teachers perceived communication, problem-solving, collaboration, critical thinking, and creativity and innovation to be important. 


\subsection{Validity and Reliability of the Instruments}

The researcher and other experts in the field of mathematics education determined the face validity of the measuring scale. After the face validation, the instrument was piloted among mathematics teachers. According to Creswell (2014), an instrument is valid when it measures what it intends to measure. The reliability of the items that were used to establish mathematics teachers' perceptions of soft skills integration, was found to have an acceptable internal consistency - the Cronbach's alpha coefficient was 0.851 .

\subsection{Data Analysis}

Different methods were used to analyze and interpret the data that were collected. The Statistical Package for Social Sciences (SPSS) (IBM Corp., 2015) was used to derive frequencies, means, standard deviations, sample $t$-test and analysis of variance (ANOVA). First, a normality test was conducted on the data gathered from the questionnaire; the results are as shown in Table 3.

Table 3: Normality Test Results

\begin{tabular}{lcccccc}
\hline & \multicolumn{3}{c}{ Kolmogorov-Smirnov $^{\mathbf{a}}$} & \multicolumn{3}{c}{ Shapiro-Wilk } \\
\cline { 2 - 7 } & Statistic & Df & Sig. & Statistic & df & Sig. \\
\hline $\begin{array}{l}\text { Mathematics teachers' } \\
\begin{array}{l}\text { perceptions of soft skills } \\
\text { integration }\end{array}\end{array}$ & .091 & 81 & .093 & .972 & 81 & .076 \\
\hline
\end{tabular}

a Lilliefors significance correction

Table 3 indicates the results of the normality test with Kolmogorov-Smirnov ( $p$ value of .093) and Shapiro-Wilk (p-value .076). The significance values are greater than .05. Thus, we can conclude with confidence that our data are normally distributed. Furthermore, our data cluster around the trend line, as can be seen on the Q-Q plot indicated in Figure 1.

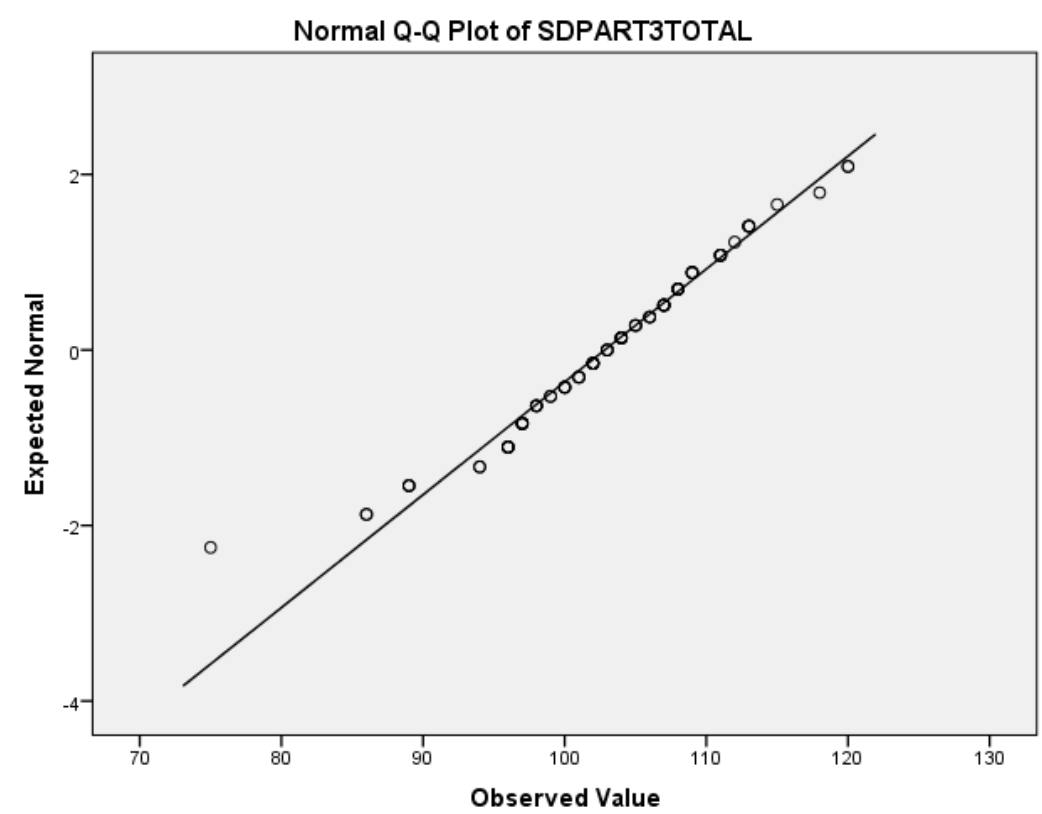

Figure 1: Normal Q-Q plot for Mathematics Teachers' Perceptions of Integration of Soft Skills 
Figure 1 offers further evidence that the distribution was normal and that, at least, the criterion for parametric statistical testing was satisfied.

\section{Findings}

5.1 Mathematics Teachers' Perceptions of Soft Skills Integration in Mathematics Teaching and Learning

To respond to research question 1, which aimed to establish perceptions of mathematics teachers in relation to soft skills integration in mathematics teaching and learning in Zambian secondary schools, a 5-point Likert scale was used. Table 4 reports on the frequencies, percentages, means (M) and standard deviations (SD) of the mathematics teachers' perceptions of soft skills integration in mathematics teaching and learning. In Table 4. SD, D, U, A and SA represent Strongly Disagree, Disagree, Uncertain, Agree and Strongly Agree, respectively.

Table 4: Mathematics Teachers' Perceptions about Soft Skills Integration in Mathematics Teaching and Learning $(n=81)$

\begin{tabular}{|c|c|c|c|c|c|c|c|c|}
\hline \multirow{2}{*}{ SN } & \multirow{2}{*}{ Statement } & \multicolumn{5}{|c|}{ Frequency } & \multirow[t]{2}{*}{$\mathbf{M}$} & \multirow[t]{2}{*}{ SD } \\
\hline & & SD & D & $\mathbf{U}$ & $\mathrm{A}$ & SA & & \\
\hline 1 & $\begin{array}{l}\text { Facilitating class } \\
\text { discussions allows soft } \\
\text { skills integration }\end{array}$ & & & $8(10 \%)$ & $39(48 \%)$ & $34(42 \%)$ & 4.32 & 0.65 \\
\hline 2 & $\begin{array}{l}\text { It is a teachers' role to } \\
\text { support students' growth } \\
\text { in collaborative skills }\end{array}$ & & & $4(5 \%)$ & $45(55 \%)$ & $32(40 \%)$ & 4.35 & 0.57 \\
\hline 3 & $\begin{array}{l}\text { Providing students with } \\
\text { problem-solving situations } \\
\text { to investigate in small } \\
\text { groups enhances } \\
\text { collaborative skills }\end{array}$ & & $2(3 \%)$ & $5(6 \%)$ & $38(47 \%)$ & $36(44 \%)$ & 4.33 & 0.71 \\
\hline 4 & $\begin{array}{l}\text { Using cooperative } \\
\text { learning approaches is key } \\
\text { to developing soft skills }\end{array}$ & & $3(4 \%)$ & $10(12 \%)$ & $46(57 \%)$ & $22(27)$ & 4.07 & 0.74 \\
\hline 5 & $\begin{array}{l}\text { Mathematics supports } \\
\text { students' growth in critical } \\
\text { thinking/ problem- } \\
\text { solving }\end{array}$ & & & $6(7 \%)$ & $21(26 \%)$ & $54(67 \%)$ & 4.59 & 0.63 \\
\hline 6 & $\begin{array}{l}\text { Mathematics content must } \\
\text { be presented in the correct } \\
\text { sequence }\end{array}$ & & $1(1 \%)$ & $4(5 \%)$ & $38(47 \%)$ & $38(47 \%)$ & 4.40 & 0.65 \\
\hline 7 & $\begin{array}{l}\text { Students learn actively } \\
\text { through finding solutions } \\
\text { independently of } \\
\text { mathematical problems } \\
\text { provided by teachers }\end{array}$ & & $1(1 \%)$ & $9(11 \%)$ & $46(57 \%)$ & $25(31 \%)$ & 4.17 & 0.67 \\
\hline 8 & $\begin{array}{l}\text { Mathematics involves } \\
\text { problem solving, figuring } \\
\text { out relationships, and } \\
\text { patterns }\end{array}$ & & & $3(4 \%)$ & $39(48 \%)$ & $39(48 \%)$ & 4.44 & 0.57 \\
\hline 9 & $\begin{array}{l}\text { Teachers facilitate } \\
\text { students' communication }\end{array}$ & & $2(3 \%)$ & $9(11 \%)$ & $49(61 \%)$ & $21(26 \%)$ & 4.10 & 0.68 \\
\hline
\end{tabular}


10 Learning is enhanced when students explain and demonstrate their

$$
1(1 \%) \quad 4(5 \%) \quad 32(40 \%) 44(54 \%) \quad 4.47 \quad 0.65
$$

solutions to others

11 Using media supports teaching and learning of mathematics

$\begin{aligned} & 3(4 \\ & \%)\end{aligned}$
$\%(5 \%)$

12 Teachers support students' growth in communication skills

13 Mathematics involves creativity and new ideas that can be tried

1
$1 \%)$ $2(3 \%) 8(10 \%) 30(37 \%) 40(49 \%) 4.31 \quad 0.85$ independently

14 Students should be given the opportunity to think independently about mathematics problems before the teacher shows how to solve them

15 Mathematics teaching should assist students to develop an attitude of inquiry (asking questions, being curious about solutions)

16 Teachers support students' growth in creative and innovative skills

17 Mathematical content is best presented in an expository style: demonstrating, explaining and describing concepts and skills

18 Teachers can integrate soft skills in mathematics using problem-based learning

19 Teachers should determine the soft skills needs of their students

20 Incorporating inquirybased learning allows soft skills integration

21 Teachers can assess students' growth in collaborative skills

22 Teachers can assess students' growth in critical thinking/ problemsolving 
23 Teachers can assess students' growth in creative and innovative $3(4 \%) \quad 51(63 \%) 27(33 \%) \quad 4.30 \quad 0.53$ skills

24 Teachers can assess students' growth in communication skills

Analysis of mathematics teachers' perceptions of soft skills integration, as measured by the 24 statements listed in Table 4, exposed high mean scores, on average between $M \geq 3.84$ and $M \leq 4.59$. All the items had mean scores above 4, except item 11 (Using media supports teaching and learning of mathematics), which had a mean score of 3.82. This item's mean score was lower than that of other items due to teachers and students at most Zambian schools lack adequate access to information and communication technology(ICT) tools. This conclusion is confirmed by a recent study by Mukuka et al. (2021), who report that there is a need to improve the infrastructure of the Zambian education system, so that it can support the use of media for learning and teaching mathematics. However, from the results obtained, it can be concluded that mathematics teachers at Zambian secondary schools have positive perceptions of soft skills integration in mathematics teaching and learning.

\subsection{Mathematics Teachers' Perceptions on the Importance of Soft Skills Integration in Mathematics teaching and learning}

To respond to research question 2, the study explored and analysed mathematics teachers' perceptions on the importance of soft skills integration in mathematics teaching and learning. Once again, a 5-point Likert scale with values that ranged from not important (1) to extremely important (5) was used in the conceptual understanding test that was administered to 91 mathematics teachers in Mazabuka District in Zambia. Table 5 reports the frequencies, percentages, means and standard deviations of mathematics teachers' perceptions on the importance of soft skills integration in mathematics in secondary school. In Table 5, NI, MBI, I, MI and EI represent Not Important, Maybe Important, Important, More Important and Extremely Important, respectively. 
Table 5: Mathematics Teachers' Perceptions of the Importance of Soft Skills Integration in Mathematics Teaching and Learning $(n=91)$

\begin{tabular}{|c|c|c|c|c|c|c|c|c|}
\hline \multirow{2}{*}{$\begin{array}{l}\text { Importance of students } \\
\text { possessing the following } \\
\text { abilities in mathematics }\end{array}$} & \multirow{2}{*}{ Description } & \multicolumn{7}{|c|}{ Frequency } \\
\hline & & NI & MBI & I & MI & EI & $\mathbf{M}$ & SD \\
\hline $\begin{array}{l}\text { a) The students' } \\
\text { ability to work effectively in } \\
\text { groups/in pairs/or as a } \\
\text { whole class in order to } \\
\text { achieve group goals in a } \\
\text { mathematics lesson }\end{array}$ & Collaboration & & $1(1 \%)$ & $9(10 \%)$ & $25(28 \%)$ & $56(62 \%)$ & 4.49 & 0.72 \\
\hline $\begin{array}{l}\text { b) The students' ability to find } \\
\text { ffective solutions to problems } \\
\text { Ising different approaches to } \\
\text { rrive at the correct solutions } \\
\text { o a mathematical problem }\end{array}$ & Problem-solving & $1(1 \%)$ & $4(4 \%)$ & $5(6 \%)$ & $31(34 \%)$ & $50(55 \%)$ & 4.37 & 0.86 \\
\hline $\begin{array}{l}\text { c) The students' ability to } \\
\text { present mathematical } \\
\text { concepts in written or verbal } \\
\text { form to a group, class or in } \\
\text { speaking to peers. }\end{array}$ & Communication & & $1(1 \%)$ & $11(12 \%)$ & $24(26 \%)$ & $55(50 \%)$ & 4.46 & 0.75 \\
\hline $\begin{array}{l}\text { d) The students' ability to } \\
\text { initiate mathematical ideas } \\
\text { and concepts that translate } \\
\text { into new knowledge and/or } \\
\text { ideas }\end{array}$ & $\begin{array}{l}\text { Creativity and } \\
\text { innovation }\end{array}$ & & $4(4 \%)$ & $2(2 \%)$ & $33(36 \%)$ & $52(57 \%)$ & 4.46 & 0.75 \\
\hline
\end{tabular}

Table 5 reports on mathematics teachers' perceptions of the importance of soft skills integration in mathematics. The items numbered (c) and (d) both had mean scores of $\geq 4.46$. Item numbered (a) had the highest mean score (4.49), while item numbered (b) had the lowest mean score (4.37). The high mean scores suggest that mathematics teachers believe that soft skills integration in mathematics is important. These results confirm the findings of Free (2017), who found that agriculture teachers who participated in a study perceived soft skills to be very important - in this study the mean score was 4.22 .

\subsection{Relationship between Mathematics Teachers' Demographic Factors and their Perceptions about Soft Skills Integration}

The study also investigated whether mathematics teachers' demographic factors, specifically, gender, type of school, age, level of education and experience, influenced their perceptions of soft skills integration in mathematics teaching and learning in Zambian secondary schools. To establish this relation, the researcher conducted two parametric tests, namely independent sample t-test and analysis of variance (ANOVA).

\subsubsection{Independent sample t-test to compare male and female mathematics} teachers' scores on perceptions of soft skills integration

An independent-samples t-test was conducted to compare the male and female mathematics teachers' scores on perceptions about soft skills integration in 
mathematics teaching and learning in Zambian secondary schools. The t-test results are displayed in Table 6.

Table 6: Independent Sample t-test Comparing Male and Female Mathematics Teachers' Scores on Perceptions Towards Soft Skills Integration $(n=81)$

\begin{tabular}{lcccccc}
\hline \multicolumn{1}{c}{ Gender } & N & \multicolumn{1}{c}{$\boldsymbol{M}$} & SD & $\boldsymbol{t}$ & $\boldsymbol{d}$ & $\boldsymbol{p}$ \\
\hline & & & & .734 & 79 & .465 \\
Male & 48 & 103.35 & 5.49 & & & \\
Female & 33 & 102.06 & 10.28 & & & \\
Total & $\mathbf{8 1}$ & & & & & \\
\hline
\end{tabular}

Table 6 reveals that there were no significant differences between mean scores for male mathematics teachers $(M=103.35 ; S D=5.49)$ and female mathematics teachers, $(M=102.06 ; S D=10.28)$ regarding their perceptions of soft skills integration in mathematics teaching and learning in Zambian secondary schools, $t(79)=.734, p=.465$ (two-tailed) with reported Cohen's $d=0.2$. The formula,

$$
\text { Cohen's } d=\frac{\mathrm{M}_{2}-M_{1}}{S D_{\text {pooled }}} \text {, where } S D_{\text {pooled }}=\sqrt{\frac{S D_{1}{ }^{2}+S D_{2}{ }^{2}}{2}}
$$

was used to calculate the effect size for independent samples t-test (Thalheimer \& Cook, 2002). This implies that gender did not affect the perceptions mathematics teachers had about soft skills integration in mathematics teaching and learning in Zambian secondary schools.

\subsubsection{One-way ANOVA test on mathematics teachers' scores for perceptions of soft skills integration}

Before conducting analysis of variance (ANOVA), the researcher ensured that assumptions, such as that the dependent variables were normally distributed for each group, that the observations were independent, and that the variances on the dependent variable were equal across groups, were satisfied (Morgan et al., 2011). A one-way between-group analysis of variance (ANOVA) test was conducted to explore mathematics teachers' scores in relation to their perceptions of soft skills integration in mathematics teaching and learning in Zambian secondary schools. Group variables were type of school where teachers were teaching, age, experience and qualification. The computed data are displayed in Table 7.

Table 7: Mathematics Teachers' Scores on Perceptions Towards the Integration of Soft Skills for Four Group Variables $(n=81)$

\begin{tabular}{llllllll}
\hline \multicolumn{1}{c}{ Factors } & & $\mathbf{N}$ & $\mathbf{M}$ & $\mathbf{S D}$ & $\boldsymbol{d f}$ & $\mathbf{F}$ & $\boldsymbol{p}$ \\
\hline $\begin{array}{l}\text { Type of school } \\
\text { where }\end{array}$ & $\begin{array}{l}\text { Non-public } \\
\text { mathematics }\end{array}$ & 44 & 102.61 & 8.14 & 1 & .072 & .789 \\
$\begin{array}{l}\text { Schools } \\
\text { teaching were }\end{array}$ & Public schools & 37 & 103.08 & 7.42 & 79 & & \\
& & & & & & &
\end{tabular}




\begin{tabular}{|c|c|c|c|c|c|c|c|}
\hline & Total & 81 & 102.83 & 7.77 & 80 & & \\
\hline \multirow{3}{*}{ Age (in years) } & $25 \leq X \leq 34$ & 35 & 103.17 & 6.35 & 1 & .120 & .730 \\
\hline & $35 \leq X \leq 54$ & 46 & 102.57 & 8.77 & 79 & & \\
\hline & Total & 81 & 102.83 & 7.77 & 80 & & \\
\hline \multirow{5}{*}{$\begin{array}{l}\text { Mathematics } \\
\text { teachers' } \\
\text { education level }\end{array}$} & $\begin{array}{l}\text { Diploma in } \\
\text { Education }\end{array}$ & 45 & 102.91 & 6.85 & 1 & .012 & .914 \\
\hline & Bachelor's & & & & & & \\
\hline & Degree in & 36 & 102.72 & 8.90 & 79 & & \\
\hline & Education & & & & & & \\
\hline & Total & 81 & 102.83 & 7.77 & 80 & & \\
\hline \multirow{3}{*}{$\begin{array}{l}\text { Experience (in } \\
\text { years) }\end{array}$} & $1 \leq X \leq 10$ & 44 & 103.00 & 6.99 & 1 & .047 & .829 \\
\hline & $11 \leq X \leq 30$ & 37 & 102.62 & 8.71 & 79 & & \\
\hline & Total & 81 & 102.83 & 7.77 & 80 & & \\
\hline
\end{tabular}

One-way ANOVA results in Table 7 indicate that there were no statistically significant differences regarding mathematics teachers' scores on perceptions towards soft skills integration in Zambian secondary schools, and any of the four variables. The variables were the type of school where mathematics teachers were teaching $(F(1,79)=.072, p=.789)$, age of mathematics teachers $(F(1,79)=$ $.120, p=.730)$, their education level $(F(1,79)=.047, p=.829)$ and their experience of teaching mathematics $(F(1,79)=.012, p=.914)$. The conclusion drawn from these results is that the type of school where mathematics teachers were teaching, teachers' ages, professional qualifications and experience did not influence the perceptions that teachers had of soft skills integration in the teaching and learning of mathematics at Zambian secondary schools.

The analysis of the results revealed that mathematics teachers had a positive perception of the integration of soft skills in teaching and learning of mathematics in Zambian secondary schools.

\section{6. Discussions and Implications}

\subsection{Mathematics Teachers' Perceptions of Soft Skills Integration in Mathematics}

The analysis of the results reveals that mathematics teachers had a positive perception of the integration of soft skills in teaching and learning of mathematics in Zambian secondary schools. Their responses to the 24 statements of the questionnaire show a high mean score - between $\mathrm{M} \geq 3.84$ and $\mathrm{M} \leq 4.59$. These results are similar to that of Free (2017), who found that secondary teachers had a very positive perception $(\mathrm{M} \geq 4.75)$ for the importance of integrating soft skills into curricula. Similarly, a study by Subramaniam (2013) found that teachers were aware of the importance of soft skills integration in the teaching and learning process. Furthermore, mathematics teachers' positive perceptions of soft skills integration in mathematics teaching and learning could influence the way they are motivated and encouraged to integrate the soft skills (Minarni et al., 2018; Subramaniam, 2013). This is in line with social cognitive theorists' view that positive perceptions impact one's capacity to positively 
influence how much much effort one puts in (Bandura, 1997; Darling-Hammond et al., 2002) and, consequently, the way one integrates soft skills. Furthermore, the beliefs that mathematics teachers hold cannot be separated from their knowledge and competency (Minarni et al., 2018). Hence, mathematics teachers' beliefs regarding soft skills integration in teaching and learning have a bearing on their ability to integrate these skills in mathematics.

\subsection{Mathematics Teachers' Perceptions on the Importance of Soft Skills Integration in Mathematics Teaching and Learning}

The study, furthermore, established what mathematics teachers' perceptions were regarding the importance of soft skills integration in mathematics teaching and learning. The results generated mean scores between $M \geq 4.37$ and $M \geq 4.49$. The high mean scores recorded suggest that mathematics teachers believed that integrating soft skills in mathematics was important. These results confirm the findings of Free (2017), who found that agricultural science teachers who took part in a study perceived soft skills to be very important $(M \geq 4.22)$. Flores (2015) agrees that mathematics teachers' perceptions of the importance of integrating soft skills in mathematics teaching and learning are related to the thoughts and behaviors of the teachers. Minarni et al. $(2018$, p. 1) state that "mathematics teachers' beliefs guide them to determine the teaching practices considered correct". Thus, mathematics teachers' perception of the importance of soft skills could enable them to choose the best approaches to achieving soft skills integration.

\subsection{Mathematics Teachers' Demographic Factors and their Perceptions on Soft Skills Integration in Mathematics Teaching and Learning}

The study, furthermore, determined the relationships between demographic factors, such as gender, type of school, age, level of education, and experience, and mathematics teachers' perceptions on soft skills integration in mathematics teaching and learning. The independent t-test found no significant differences between male and female mathematics teachers' perceptions on soft skills integration. The results are similar to that of Emmanuel and Frank (2020), who found no significant differences between male and female teachers' perceptions regarding soft skills integration. The one-way ANOVA test applied in this study revealed that the type of school where mathematics teachers were teaching, their ages, professional qualifications and experience, did not influence the perceptions of teachers on soft skills integration in teaching and learning mathematics in Zambian secondary schools. The results reveal that none of the demographic factors considered by the study influenced the perceptions teachers hold on soft skills integration in mathematics teaching and learning in Zambian secondary schools.

\section{Conclusion}

The study concludes that mathematics teachers in Zambian secondary schools had positive perceptions of soft skills integration in mathematics teaching and learning - teachers believed that integrating soft skills in mathematics teaching and learning was important. Furthermore, the results reveal that gender, the type of school where mathematics teachers were teaching, age, level of education and experience did not influence teachers' perceptions of soft skills 
integration in teaching and learning mathematics in Zambian secondary schools. Thus, this study raises awareness of mathematics teachers' perceptions of soft skills integration and their beliefs regarding the importance of integrating soft skills in mathematics teaching and learning.

\section{Recommendation}

The researchers recommend that further research is conducted to establish how well mathematics teachers at secondary schools in Zambia integrate soft skills in mathematics teaching and learning, since the instruments used by this study do not indicate how well soft skills are actually integrated.

\section{Acknowledgement}

The authors thank the African Centre of Excellence for Innovative Teaching and Learning Mathematics and Science (ACEITLMS), University of Rwanda, for financial support.

\section{References}

Agcam, R., \& Dogan, A. (2021). A study on the soft skills of pre-service teachers. International Journal of Progressive Education, 17(4), 35-48. https:// doi.org/10.29329/ijpe.2021.366.3

Baker, C. N., Tichovolsky, M. H., Kupersmidt, J. B., Voegler-Lee, M. E., \& Arnold, D. H. (2015). Teacher (mis)perceptions of pre-schoolers' academic skills: Predictors and associations with longitudinal outcomes. Journal of Educational Psychology, 107(3), 805-820. https://doi.org/10.1037/edu0000008

Bandura, A. (1997). Self-efficacy: The exercise of control. W. H. Freeman.

Calhoun, P. B. (2019). Mathematics teachers' perceptions of self-efficacy: effects of teacher characteristics and supervisory behaviours. [Doctoral dissertation, Virginia Polytechnic Institute and State University].

Cauce, A. M., \& Gordon, E. W. (2012). Toward the measurement of human agency and the disposition to express it. The Gordon Commission. https://www.ets.org/Media/Research/pdf/cauce_gordon_measurement_hum an_agency.pdf

Creswell, J. W. (2014). Research design: Qualitative, quantitative, and mixed methods approaches (4th ed.). Sage Publications.

CDC [Curriculum Development Centre]. (2013a). 2013 Zambia education curriculum framework. MESVTEE.

CDC [Curriculum Development Centre]. (2013b). Teachers' curriculum implementation guide: Guidance to enable teachers to make best use of the Zambia education curriculum framework 2013 (No. 1). Ministry of General Education.

CDC [Curriculum Development Centre]. (2013c). Mathematics syllabus (Grades 8 and 9). MESVTEE.

Darling-Hammond, L., Chung, R., \& Frelow, F. (2002). Variation in teacher preparation: How well do different pathways prepare teachers to teach? Journal of Teacher Education, 53(4), 286-302. https:// doi.org/10.1177/0022487102053004002

DiMartino, J., \& Castaneda, A. (2007). Assessing applied skills. Educational Leadership, 64(7), 38-42.

Emmanuel, N., \& Frank, O. O. (2020). Teachers' perception toward the integration of soft skills in teaching business studies in secondary schools in rivers state. Vocational and Technology Education Journal (VOTEJ), 2(1), 39-48. 
Fernandes, P. R. d. S., Jardim, J., \& Lopes, M. C. d. S. (2021). The soft skills of special education teachers: Evidence from the literature. Education Sciences, 11(3), 1-13. https://doi.org/10.3390/educsci11030125

Flores, I. M. (2015). Developing preservice teachers' self-efficacy through field-based science teaching practice with elementary students. Research in Higher Education Journal, 27(1), 1-19.

Free, D. L. (2017). Perceptions of soft skill development in secondary agricultural education programs by agricultural teachers. [Doctoral dissertation, Auburn University].

Gibb, S. (2014). Soft skills assessment: theory development and the research agenda. International Journal of Lifelong Education, 33(4), 455-471. https://doi.org/10.1080/02601370.2013.867546

GPE [Global Partnership for Education]. (2020). 21st Century Skills: What potential role for the global partnership for education? A landscape review (Issue January). https://www.globalpartnership.org/sites/default/files/document/file/202001-GPE-21-century-skills-report.pdf

Hoy, A. W., \& Spero, R. B. (2005). Changes in teacher efficacy during the early years of teaching: A comparison of four measures. Teaching and Teacher Education, 21(4), 343-356. https://doi.org/10.1016/j.tate.2005.01.007

IBM Corp. (2015). IBM SPSS Statistics for Windows, Version 23.0.

KICD [Kenya Institute of Curriculum Development]. (2017). Basic education curriculum framework. Ministry of Education.

Kobalia, K., \& Garakanidze, E. (2010). The professional competencies of the 21 St century school teacher. Problems of Education in the 21st Century, 20(1), 104-108.

Mailizar, M., Hidayat, M., \& Artika, W. (2021). The effect of demographic variables on mathematics teachers' TPACK: Indonesian context. Journal of Physics: Conference Series, 1882(1), 1-9. https:// doi.org/10.1088/1742-6596/1882/1/012041

Minarni, B. W., Retnawati, H., \& Nugraheni, T. V. (2018). Mathematics teachers' beliefs and its contribution toward teaching practice and student achievement. Journal of Physics: Conference Series, 1097(1), 1-10. https://doi.org/10.1088/17426596/1097/1/012143

Morgan, G. A., Leech, N. L., Gloeckner, G. W., \& Barrett, K. C. (2011). IBM SPSS for introductory statistics: Use and interpretation (4th ed.). Routledge. http:/ / books.google.com/books?id=yhgGfAEACAAJ\&pgis=1

Mukuka, A., Shumba, O., \& Mulenga, H. M. (2021). Students' experiences with remote learning during the COVID-19 school closure: implications for mathematics education. Heliyon, 7(7), 1-6. https:// doi.org/10.1016/j.heliyon.2021.e07523

Partnership for 21st Century. (2009). Framework for 21st century learning.

Quieng, M. C., Lim, P. P., \& Lucas, M. R. D. (2015). 21st Century-based soft skills: spotlight on non-cognitive skills in a cognitive-laden dentistry program. European Journal of Contemporary Education, 11(1), 72-81. https://doi.org/10.13187/ejced.2015.11.72

Ridenour, C.S, \& Newman, I. (2008). Mixed methods research: Exploring the interactive continuum. South Illinois University Press.

Rini, D. E. P., \& Prabawanto, S. (2021). Mathematics teachers' perception of learning models associated with high school students' critical thinking skills. Journal of Physics: Conference Series, 1806(1), 1-8. https://doi.org/10.1088/17426596/1806/1/012080

REB [Rwanda Education Board]. (2015). Curriculum framework: Pre-primary to upper secondary 2015. In Competence based curriculum. REB/MINEDUC. 
Saunders, M., Lewis, P., \& Thornhill, A. (2016). Research methods for business students (7th ed.). Pearson.

Sharma, M. (2009). How important are soft skills from the recruiter's perspective? ICFAI Journal of Soft Skills, 3(2), 19-28.

Solórzano, J., Rojas, Y., Vargas, C., Rueda, O., \& Hernandez, P. H. (2018). Soft skills and advantages for learning mathematics at an early age. Indian Journal of Science and Technology, 11(45), 1-7. https://doi.org/10.17485/ijst/2018/v11i45/137683

Subramaniam, I. (2013). Teachers' perception on their readiness in integrating soft skills in the teaching and learning. IOSR Journal of Research \& Method in Education (IOSRJRME), 2(5), 19-29. https://doi.org/10.9790/7388-0251929

Susilawati, S., Aznam, N., Paidi, Hw., \& Ngadimin. (2020). Teachers' perspectives toward soft skills in science learning. Journal of Physics: Conference Series, 1460(1), 1-7. https://doi.org/10.1088/1742-6596/1460/1/012111

Sutton, N. (2002). Why can't we all just get along? Computing Canada, 28(16), 20.

Teddlie, C., \& Tashakkori, A. (2009). Foundations of mixed methods research: integrating quantitative and qualitative approaches in the social and behavioural sciences. Sage.

Thalheimer, W., \& Cook, S. (2002). How to calculate effect sizes from published research: a simplified methodology. Work Learning Research, August, 1-9. https://pdfs.semanticscholar.org/d7f0/c3a171ffd6bad4297feeb708a2d79e06da8 b.pdf?_ga=2.149295606.1950164162.1568100777-2068894367.1568100777

Umugiraneza, O., Bansilal, S., \& North, D. (2017). Exploring teachers' practices in teaching mathematics and statistics in KwaZulu-Natal schools. South African Journal of Education, 37(2), 1-13. https:// doi.org/10.15700/saje.v37n2a1306

Yarkwah, C. (2020). Junior high school mathematics teachers' beliefs and their instructional practices and its effects on students' academic performance. European Journal of Training and Development Studies, 7(3), 1-25. 


\section{Appendix 1}

Part 3: Teachers' perceptions and their instructional practices on the integration of soft skills in mathematics at secondary school

\section{INSTRUCTIONS:}

Put a Tick $(\sqrt{ })$ in the appropriate box that suits your response to the given statement where

SD (Strongly Disagree), D (Disagree), U (Uncertain), A (Agree), and SA (Strongly Agree).

\begin{tabular}{|c|c|c|c|c|c|c|}
\hline SN & Statements & SD & D & $\mathrm{U}$ & $\mathbf{A}$ & SA \\
\hline 1 & Facilitating class discussions allows soft skills integration & & & & & \\
\hline 2 & $\begin{array}{l}\text { It is a teacher's role to support students' growth in } \\
\text { collaborative skills }\end{array}$ & & & & & \\
\hline 3 & $\begin{array}{l}\text { Providing students with problem solving situations to } \\
\text { investigate in small groups enhances collaborative skills }\end{array}$ & & & & & \\
\hline 4 & $\begin{array}{l}\text { Using cooperative learning approaches is key in } \\
\text { developing soft skills }\end{array}$ & & & & & \\
\hline 5 & $\begin{array}{l}\text { Mathematics supports students' growth in critical } \\
\text { thinking/problem solving }\end{array}$ & & & & & \\
\hline 6 & $\begin{array}{l}\text { Mathematics content must be presented in the correct } \\
\text { sequence }\end{array}$ & & & & & \\
\hline 7 & $\begin{array}{l}\text { Students learn actively through finding solutions } \\
\text { independently of mathematical problems provided by } \\
\text { teachers }\end{array}$ & & & & & \\
\hline 8 & $\begin{array}{l}\text { Mathematics involves problem solving, figuring out } \\
\text { relationships, and patterns }\end{array}$ & & & & & \\
\hline 9 & $\begin{array}{l}\text { Teachers facilitate students' communication in } \\
\text { Mathematics }\end{array}$ & & & & & \\
\hline 10 & $\begin{array}{l}\text { Learning is enhanced when students explain and } \\
\text { demonstrate their solutions to others }\end{array}$ & & & & & \\
\hline 11 & $\begin{array}{l}\text { Using media supports teaching and learning of } \\
\text { Mathematics }\end{array}$ & & & & & \\
\hline 12 & Teachers support students' growth in communication skills & & & & & \\
\hline 13 & $\begin{array}{l}\text { Mathematics involves creativity and new ideas that can be } \\
\text { tried independently }\end{array}$ & & & & & \\
\hline 14 & $\begin{array}{l}\text { Students should be given the opportunity to think } \\
\text { independently about Mathematics problems before the } \\
\text { teacher shows how to solve them }\end{array}$ & & & & & \\
\hline 15 & $\begin{array}{l}\text { Mathematics teaching should assist students to develop an } \\
\text { attitude of inquiry (asking questions, being curious about } \\
\text { solutions) }\end{array}$ & & & & & \\
\hline 16 & $\begin{array}{l}\text { Teachers support students' growth in creative and } \\
\text { innovative skills }\end{array}$ & & & & & \\
\hline 17 & $\begin{array}{l}\text { Mathematical content is best presented in an expository } \\
\text { style: demonstrating, explaining, and describing concepts }\end{array}$ & & & & & \\
\hline
\end{tabular}




\begin{tabular}{|c|l|l|l|l|l|}
\hline & and skills, & & & \\
\hline 18 & $\begin{array}{l}\text { Teachers can integrate soft skills in Mathematics using } \\
\text { Problem-Based Learning }\end{array}$ & & & \\
\hline 19 & $\begin{array}{l}\text { Teachers should determine the soft skills needs of their } \\
\text { students }\end{array}$ & & & & \\
\hline 20 & $\begin{array}{l}\text { Incorporating inquiry-based learning allows soft skills } \\
\text { integration }\end{array}$ & & & & \\
\hline 21 & Teachers can assess students' growth in collaborative skills & & & & \\
\hline 22 & $\begin{array}{l}\text { Teachers can assess students' growth in critical thinking/ } \\
\text { problem solving }\end{array}$ & & & & \\
\hline 23 & $\begin{array}{l}\text { Teachers can assess students' growth in creative and } \\
\text { innovative skills }\end{array}$ & & & & \\
\hline 24 & $\begin{array}{l}\text { Teachers can assess students' growth in communication } \\
\text { skills }\end{array}$ & & & \\
\hline
\end{tabular}




\section{Appendix 2}

This section appeared in a conceptual understanding and was used to establish how mathematics teachers perceived the importance of communication, collaboration, critical thinking/problem solving, creativity and innovations.

In your opinion, how important are the following in learning Mathematics.

Please CIRCLE the number that corresponds with your opinion on the importance of:

a. the students' ability to work effectively in groups/in pairs/ or as a whole class in order to achieve group goals in a Mathematics lesson.[collaboration]

Not important

Extremely important
1
2
3
4
5

b. the students' ability to find effective solutions to problems using different approaches to arrive at the correct solutions to a mathematical problem. [critical thinking/problem solving]

Not important

Extremely important

$\begin{array}{llllll}1 & 2 & 3 & 4 & 5\end{array}$

c. the students' ability to present mathematical concepts in written or verbal form to a group, class, or in speaking to peers.[communication]

Not important

Extremely important

\section{1}

2

3

4

5

d. the students' ability to initiate mathematical ideas and concepts that translate into new knowledge and/or ideas.[creativity and innovation] Not important

Extremely important

1

2

3

4

5 